\title{
New Data on the Origin of Modern Man in the Levant
}

\section{Citation}

Bar-Yosef, O., B. Vandermeersch, B. Arensburg, P. Goldberg, H. Laville, L. Meignen, Y. Rak, E. Tchernov, and A.-M. Tillier. 1986. New Data on the Origin of Modern Man in the Levant. Current Anthropology 27, no. 1: 63-64.

\section{Published Version}

doi:10.1086/203389

\section{Permanent link}

http://nrs.harvard.edu/urn-3:HUL.InstRepos:12211572

\section{Terms of Use}

This article was downloaded from Harvard University's DASH repository, and is made available under the terms and conditions applicable to Other Posted Material, as set forth at http:// nrs.harvard.edu/urn-3:HUL.InstRepos:dash.current.terms-of-use\#LAA

\section{Share Your Story}

The Harvard community has made this article openly available.

Please share how this access benefits you. Submit a story.

Accessibility 


\section{REPORTS}

\section{New Data on the Origin of Modern Man in the Levant ${ }^{1}$}

by O. Bar-Yosef, B. Vandermeersch, B. Arensburg, P. Goldberg, H. Laville, L. Meignen, Y. RaK, E TCHERNOV, and A.-M. TILliER

Institute of Archaeology, Mt. Scopus, Hebrew University, Jerusalem 91905, Israel (Bar-Yosef, Goldberg)/Laboratoire d'Anthropologie, Université de Bordeaux I, 33405 Talence, France (Vandermeersch)/Department of Anatomy and Anthropology, Sackler School of Medicine, Tel-Aviv University, Ramat Aviv 69978, Israel (Arensburg, Rak)/Institut de Quaternaire, Université de Bordeaux I, 33405 Talence, France (Laville)/Centre de Recherches Archéologiques, Sophia Antipolis, 06565 Valbonne, France (Meignen)/De partment of Zoology, Hebrew University, Jerusalem 91904, Israel (Tchernov)/Laboratoire de Paléontologie des Vertébrés, Université de Paris VI, 4 Place Jussieu, 75006 Paris, France (Tillier). 5 IV 85

The origin of modern man in the Near East has been a controversial subject since the discoveries of human remains by Garrod, McCown, and Neuville in the caves of Tabūn, Skhūl, and Qafzeh, respectively (Garrod and Bate 1937, McCown and Keith 1939, Neuville 1951). Recent excavations at Tabūn $(1967-72)$ by Jelinek (1982a) and at Qafzeh (1965-1979) by Vandermeersch (1981) refocused attention on this issue.

The new excavations at Tabūn provided a detailed stratigraphy for the Mousterian sequence and some portion of the earlier deposits. This enabled Farrand (1979) to suggest a reconstruction of the paleoenvironmental events that were responsible for the accumulation of this remarkably thick (ca. $20 \mathrm{~m}$ ) sequence. One of the key interpretations was the correlation of the lowermost part of the sandy sequence (which contained Acheulian and "Acheulo-Yabrudian" assemblages recently named the Mugharan tradition by Jelinek) with the Last Interglacial, or Isotope Stage 5. On the basis of this suggestion, Jelinek $(1981,1982 a, b)$ plotted the results of his metrical lithic analysis, which showed a gradual decrease in the thickness of the flakes that accelerated markedly between the Early and Late Mousterian. Consequently, Jelinek suggested "an orderly and continuous progression of industries . . . paralleled by a morphological progression from Neanderthal to modern man" (Jelinek 1982a: 1374)

At Qafzeh, originally excavated by Neuville and M. Stekelis (1933-35) and recently by Vandermeersch (1965-79), the large collection of skeletal remains emanating from the lower portion of the Mousterian sequence has been assigned to Homo sapiens sapiens (Vandermeersch 1981). The age of these deposits remains controversial (Bar-Yosef and Vandermeersch 1981). Paleontological analyses of the microvertebrates by Tchernov (1981) indicate close affinities of the levels that contained the burials with the Upper Acheulian levels of Oumm-Qatafa (Neuville 1951, Haas in Neuville 1951, Tchernov 1968) and greater similarity to Tabūn D than to Tabūn C and B. These levels have been ascribed to a single biozone that Tchernov calls the "Lower Mousterian." Preliminary micromorphological analyses at Qafzeh yield the same conclusion (Goldberg 1980). At Hayonim Cave (western Galilee), the transition from the "Lower Mousterian" to the "Upper Mousterian" is also documented (Tchernov 1981). Jelinek (1982a) rejects the

${ }^{1}$ (C) 1986 by The Wenner-Gren Foundation for Anthropological Research, all rights reserved 0011-3204/86/2701-0003\$1.00. chronological correlation of Qafzeh and Tabūn, arguing that the presence of two archaic rodents (Mastomys batei and $A r$ vicanthis ectos) in the hominid-bearing layers at Qafzeh is explainable by the proximity of this site to the "refugium" of the Jordan Valley. However, both these rodents occur in Layer E at Tabūn (with the Mugharan tradition), and Mastomys was noted in the lower part of Layer E (Mousterian) at Hayonim Cave (Tchernov 1968, 1981).

Another important issue is the overall absolute dating of the Mousterian and Acheulo-Yabrudian sequence in the Levant. While Farrand (1979) maintained an incipient age of the Last Interglacial, U/Th dates for the Acheulo-Yabrudian in Zuttieyeh Cave, Wadi Amud, Israel (Schwarcz, Goldberg, and Blackwell 1980), and el Kowm, Syria (Henning and Hours 1982), indicated ages on the order of 140,000 to 150,000 B.P. Moreover, reinterpretation of the stratigraphic sequence of Tabūn indicates the possibility that Unit XIV (Layer G?) antedates the Last Interglacial (Bar-Yosef and Goren 1981).

Under the circumstances it seemed logical to try to clarify these problems by excavating a site which exhibited both good preservation of charcoal, animal bones, and human remains and a long cultural sequence. The obvious choice was Kebara Cave, which is situated ca. $13 \mathrm{~km}$ south of Tabūn at about the same altitude, overlooking the Mediterranean shoreline some 3 $\mathrm{km}$ to the west. Previous excavations at Kebara, mainly by Stekelis (1953-65), had demonstrated the potential of this site. Although Stekelis never reached bedrock, his excavations revealed an Upper Palaeolithic and a Mousterian sequence. Following his untimely death, refinements in the stratigraphy made by two of us (O. B.-Y. and E. T.) led to the publication of the lithic industries by T. Schick, of the Mousterian infant remains by Smith and Arensburg (1977), and of the mammalian remains by Davis (1977) and Tchernov (1968, 1981). Despite the abundance of charcoal remains, most of the radiocarbon dates (obtained in 1969) are aberrant, possibly because the samples were collected from sections exposed for over 15 years (Schick and Stekelis 1977).

Our reexcavation of the cave involved a multidisciplinary team covering the fields of prehistory, physical anthropology, geology, zoology, and botany. It was made possible by the support of the French Ministry of Foreign Affairs, the Permanent French Mission of the CNRS in Jerusalem, the Institute of Archaeology, Hebrew University, and the Israel Exploration Society. To date, three seasons (Fall 1982, 1983, and 1984) of what is hoped to be a long-term project have been completed. During these seasons, we have accomplished the following:

The exposed stratigraphy (after removal of most of the EpiPalaeolithic and Upper Palaeolithic layers by Turville-Petre and Stekelis) was subdivided into the generalized lithological units $1-12$, each containing a series of lenticular layers, hearths, and other geological or archaeological features. For the most part, it was possible to trace these units over much of the exposed, older sections.

Units 1-3 contain an Upper Palaeolithic industry with blades and some scrapers. These layers are tilted to the east and southeast, toward a sinkhole (or sinkholes?) into which most of the underlying Mousterian layers were collapsed. Although the sinkhole was never reached, the dip of these Mousterian layers is as much as $20-25^{\circ}$

Units 4-6 contain both Upper Palaeolithic and Mousterian artifacts and exhibit a number of features interpreted as the result of water activity, including distinct bedding, phosphatic concretions, and local breccification. The net effect is to obscure the contact between these and the overlying Upper Palaeolithic sediments.

Units 7-12 are clearly Mousterian, and the preservation of these deposits is much better than that of the later ones. All units are characterized by a dominance of fine-grained silts and clays, with some sand, all containing a large component of 
anthropic debris such as bones, hearths, white ashy deposits, and abundant lithics. Considerable disturbance of the deposits is represented by apparent rodent holes and karstic activity, which caused the partial collapse and tilting of the layers toward the rear of the cave.

The lithic industry of the Mousterian levels excavated thus far exhibits the same general characteristics as previously described (Schick and Stekelis 1977, Jelinek 1982b). Debitage products are always dominant, indicating that knapping took place inside the cave. Most of the blanks were produced by the Levallois unipolar method. Cores were peripherally prepared, with cortex left on one face and flakes or blades removed from the other. A difference was noted between Units 7-9, in which flakes are more abundant, and Units $10-12$, in which blades are.

The industry of Kebara was previously classified as "Mousterian 2-3" (Jelinek 1982b) or "Mousterian Phase 3" (Copeland 1975), a stage generally characterized by the presence of broad, short Levallois points, numerous racloirs, and a few pieces of Upper Palaeolithic types. Copeland (1975) distinguishes an older phase within this Late Mousterian in which Levallois points are accompanied by narrow, thin flakes, with an increase in blades. On the basis of the material (from only two seasons) so far analysed, it seems that the exposed sequence fits these two phases, the earlier in Units 12-10 and the later in $9-7$.

During the 1983 season, while the deepest test pit of Stekelis's excavation was being extended, a Mousterian burial was found in the uppermost portion of Unit 12 (fig. 1). The skeleton lay on its back in a shallow pit, with its right hand on its chest and its left hand on its abdomen. The jaw, with all its teeth, rested on its base, and all the cervical vertebrae were found in their original places. The skull was missing except for

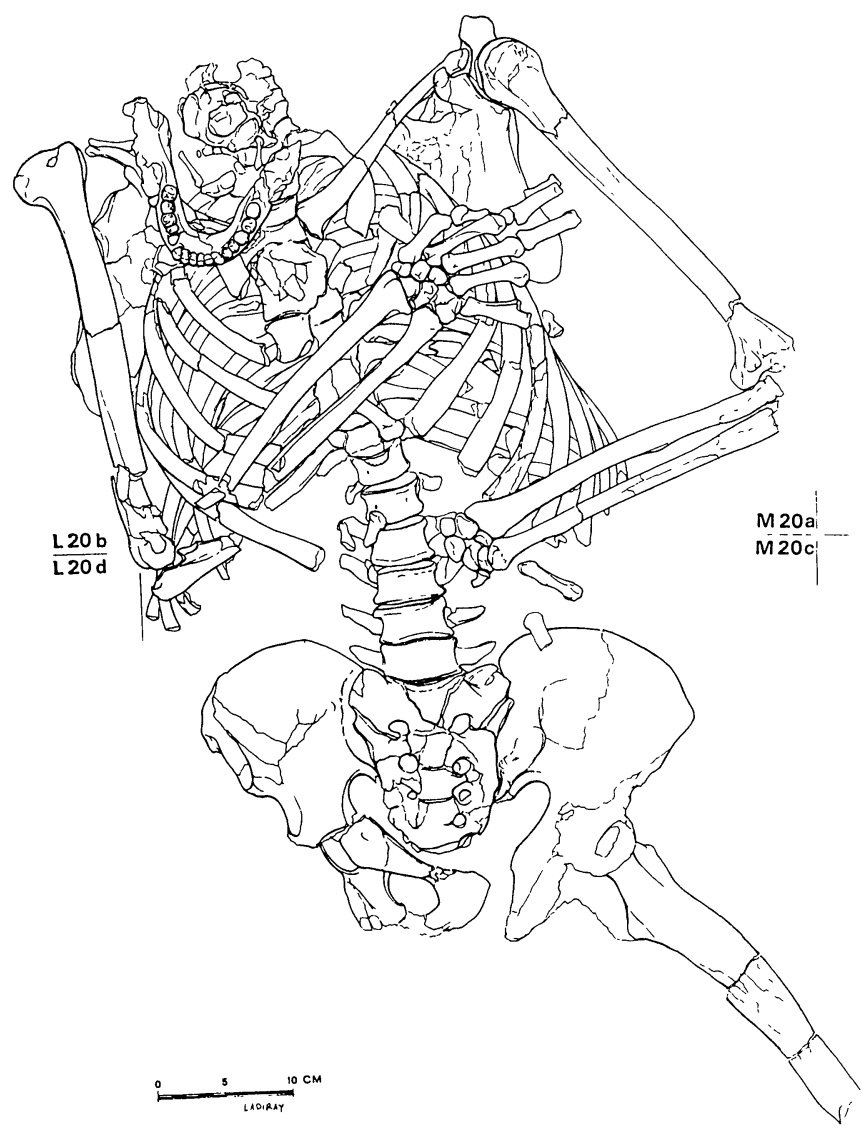

FIG. 1. Mousterian burial from uppermost portion of Unit 12 at Kebara. the right upper third molar. A large part of the postcranial skeleton was in place. Most of the lower extremities, including the right thigh bone and the remainder of the legs, were missing. The left femur (badly preserved owing to weathering) was slanted at an angle of $45^{\circ}$ from the main axis, cropping at the section of the deep sounding. Its poor condition explains why it passed unnoticed by Stekelis when he excavated this test pit. Most of the bones present were in a remarkably good state of preservation. The characteristics of the skeleton indicate affinities with the Tabūn, Amud, and Shanidar group rather than with the Qafzeh-Skhūl one. Preliminary analysis of the lithic industry from Kebara would place it in the "Mousterian $2-3$ " as defined by Jelinek at Tabūn (Jelinek 1982b). Thus, the association of the hominid types and their lithic technotypological contexts remains problematical.

Further seasons of excavation are planned for Kebara Cave. A program of relative dating using paleontology and stratigraphy as well as absolute dating by thermoluminescence and ${ }^{14} \mathrm{C}$ accelerator methods is under way. Such efforts may permit us to place the Kebara human remains in a firm chronological context with respect to other skeletal material.

\section{References Cited}

Bar-Yosef, O., and N. GoRen. 1981. "Notes on the chronology of the Lower Palaeolithic in the southern Levant." Pre-Acheulean and Acheulean industries (Xth UISPP Congress, Mexico City). Edited by D. Clark and G. Isaac, pp. 28-42.

BAR-Yosef, O., and B. VANDERMEersCh. 1981. "Notes concerning the possible age of the Mousterian layers in Qafzeh Cave," in Préhistoire du Levant (CNRS Colloque No. 598). Edited by J. Cauvin and P. Sanlaville, pp. 281-86. Paris.

Copeland, L. 1975. "The Middle and Upper Paleolithic of Lebanon and Syria in the light of recent research," in Problems in prehistory: North Africa and the Levant. Edited by F. Wendorf and A. E. Marks, pp. 317-50. Dallas: Southern Methodist University Press.

Davis, S. 1977. The ungulate remains from Kebara Cave. Eretz Israel 13:150-63.

FARRAND, W. R. 1979. Chronology and palaeoenvironment of Levantine prehistoric sites as seen from sediment studies. Journal of Archaeological Science 6:369-92.

Garrod, D. A. E., and D. M. A. BATE. 1937. The Stone Age of Mount Carmel. Vol. 1. Oxford: Clarendon Press.

GolDBERG, P. 1980. Micromorphology in archaeology and prehistory. Paléorient 6:159-64.

Henning, J. G., and F. Hours. 1982. Dates pour le passage entre l'Acheuléen et le Paléolithique moyen a El-Kowm (Syrie). Paléorient $8: 181-84$

Jelinek, A. J. 1981. "The Middle Palaeolithic in the southern Levant from the perspective of the Tabūn Cave," in Préhistoire du Levant (CNRS Colloque No. 598). Edited by J. Cauvin and P. Sanlaville, pp. 265-80. Paris.

. 1982a. The Tabūn Cave and Paleolithic man in the Levant. Science 216:1369-75.

. 1982b. "The Middle Palaeolithic in the southern Levant, with comments on the appearance of modern Homo sapiens," in The transition from Lower to Middle Palaeolithic and the origin of man. Edited by A. Ronen, pp. 57-104. British Archaeological Reports S151.

McCown, T. D., and A. KeITh. 1939. The Stone Age of Mount Carmel. Vol. 2. Oxford: Clarendon Press.

Neuville, R. 1951. Le Paléolithique et le Mesolithique du desert de Judée. Mémoire des Archives de l'Institut de Paléontologie Humaine 24.

Schick, T., and M. Stekelis. 1977. Mousterian assemblages in Kebara Cave, Mount Carmel. Eretz Israel 13:97-149.

SChwarcz, H. P., P. Goldberg, and B. Blackwell. 1980. Uranium series dating of archaeological sites in Israel. Israel Journal of Earth Sciences 29:157-65.

Smith, P., and B. Arensburg. 1977. A Mousterian skeleton from Kebara Cave. Eretz Israel 13:164-76.

TCHERNOv, E. 1968. Succession of rodent faunas during the Upper Pleistocene of Israel. Hamburg and Berlin: Paul Parey.

1981. "The biostratigraphy of the Middle East," in Préhistoire $d u$ Levant (CNRS Colloque No. 598). Edited by J. Cauvin and P. Sanlaville, pp. 67-97. Paris.

VANDERMEERSCH, B. 1981. Les hommes fossiles de Qafzeh (Israel). Paris: CNRS. 